\title{
PENGARUH PAJAK PENGHASILAN \\ TERHADAP KESEJAHTERAAN: SUATU MODEL TEORITIS
}

\author{
Eddy Suratman \\ Fakultas Ekonomi Universitas Tanjungpura, Pontianak \\ Jalan Ahmad Yani Pontianak - Kalimantan BaratTelp/Fax.0561-739636 \\ E-mail: eddysuratman@yahoo.com
}

\begin{abstract}
Tax affects distortion on economy. To minimize the distortion, the government canonically switches the income resources to income tax from other types of tax deemed to have the least distortion. Furthermore, the increase of this income tax will affect the prosperity of the tax payers. This writing is aimed to develop a theoretical model of: firstly, change effect of income tax on income and leisure; secondly, change effect of income tax on consumptions of private goods and public goods; and thirdly, change effect of income tax on prosperities of tax payers and free rider. This writing indicates that (1) work and leisure hours are bound with time endowment, payment and property income after tax and utility parameter; (2) Income tax increase will promote leisure, thus income after tax will decrease; (3) As individuals, income tax payers can see this change positive or negative; and (4) Free riders will get their prosperity improved from income tax increase.
\end{abstract}

Keywords: income tax, prosperity, theoretical model

\section{PENDAHULUAN}

Sejak reformasi pajak dilakukan pada tahun 1984, pajak penghasilan di Indonesia telah tumbuh demikian cepat sebagai sumber pendapatan yang cukup penting. Dalam APBN 2009 pajak penghasilan memberikan kontribusi terbesar (lebih dari 50\%) pada penerimaan rutin dalam negeri yang berasal dari pajak, yaitu sebesar Rp 366,8 Trilyun dari total penerimaan pajak sebesar Rp 657,3 Trilyun. Secara umum pajak mempunyai dampak distorsi dalam perekonomian. Untuk meminimalkan distorsi itulah, maka biasanya pamerintah memindahkan sumber penerimaannya dari jenis pajak lain ke pajak penghasilan yang dianggap mempunyai beban pajak paling minimum.

Tulisan ini akan menganalisis bagaimana dampak dari pilihan terhadap pajak penghasilan sebagai sumber penerimaan dibanding sejumlah pilihan pada jenis pajak lain. Pilihan tersebut akan membawa akibat berupa meluasnya basis pajak dan atau meningkatnya tarif pajak. Selanjutnya, perubahan kesejahteraan sebagai akibat meningkatnya pajak penghasilan juga akan dianalisis. Dalam tulisan ini yang dimaksud dengan pajak penghasilan adalah pajak penghasilan perorangan/rumah tangga, pajak upah dan 
gaji, dan pajak pendapatan modal (Musgrave dan Musgrave, 1989).

Untuk menganalisis perubahan kesejahteraan tersebut, tulisan ini memasukkan penawaran tenaga kerja sebagai variabel endogen. Pekerja akan menentukan tingkat konsumsi, tabungan, dan leisure sehingga utilitasnya mencapai maksimal. Pajak penghasilan tersebut, akan mengurangi pendapatan yang dapat dibelanjakan individu yang menghasilkan adanya efek subsitusi dan efek pendapatan. Hal ini dapat dilihat pada gambar 1. Dari gambar tersebut tampak bahwa akibat kenaikan pajak penghasilan, yang berarti adanya penurunan upah, maka ulitilas individu akan menurun dari U0 ke U1 sebagai akibat adanya efek income. Dengan kata lain pada jumlah jam kerja yang sama, pekerja sekarang akan mempunyai pendapatan yang lebih rendah. Pendapatan inilah yang siap dia belanjakan untuk membeli sejumlah komoditi. Pada dasarnya kita juga dapat melihat efek subsitusi dari perubahan upah. Namun untuk penyederhanaan, pada gambar 1 efek tersebut tidak ditampilkan.
Dalam hal ini $\mathrm{W}^{\prime}=\mathrm{w}(1-\mathrm{t})$, sehingga $\mathrm{w}^{\prime}<\mathrm{w}$ dan $w^{\prime} / p<w / p$, dimana $w=$ upah; $t=$ tingkat pajak penghasilan; dan $\mathrm{p}=$ harga, sehingga $\mathrm{w} / \mathrm{p}=$ upah ril.

Dari gambar 1 kita dapat mengukur dampak dari kenaikan pajak penghasilan dengan melakukan estimasi terhadap elastisitas substitusi di antara bekerja dan leisure yang secara teoritis telah dimuat pada beberapa literatur, antara lain dapat dibaca pada Binger dan Hoffman (1988) dan Layard dan Walters (1994). Sifat endogen dari penawaran tenaga kerja sesungguhnya memungkinkan untuk mempelajari dampak efisiensi dari alternatif kebijakan perpajakan yang berpotensi untuk mendistorsi pengambilan keputusan pada penawaran tenaga kerja. Perubahan kesejahteraan dari pengenaan pajak penghasilan, akan terlihat dari berkurangnya kemampuan individu untuk membeli sejumlah barang yang dikonsumsi. Berbeda dengan beberapa model sebelumnya yang melihat bahwa tingkat kepuasan individu ditentukan oleh konsumsi dan leisure, maka dalam tulisan ini konsumsi

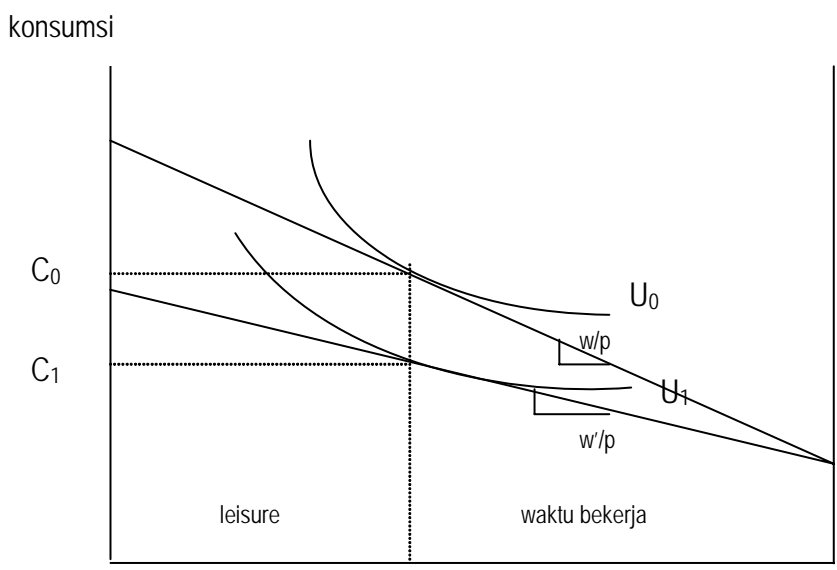

Gambar 1. Labor Supply dan Consumer Demand 
individu dibedakan dalam dua kelompok, yaitu barang privat dan barang publik. Dengan demikian pada tingkat penghasilan yang sama, individu yang membayar pajak akan mempunyai kemampuan yang lebih rendah untuk mengkonsumsi kedua barang tersebut. Hal ini dapat dilihat pada gambar 2.

Dari gambar 2 terlihat bahwa kenaikan pajak penghasilan akan mengurangi pendapatan individu. Dengan demikian bagi seorang pembayar pajak, kenaikan pajak akan mengurangi utilitasnya. Penurunan kesejahteraan akibat kebijakan pajak penghasilan tersebut tampak dari gambar 2 dimana luas equivalent variation lebih kecil dibanding consumer surplusnya. Oleh karena itu, tulisan ini bertujuan untuk membangun model teoritis tentang:

1. Dampak dari perubahan pajak penghasilan terhadap pendapatan dan leisure

2. Dampak dari perubahan pajak penghasilan terhadap konsumsi barang privat dan barang publik

3. Dampak dari perubahan pajak penghasilan terhadap kesejahteraan bagi pembayar pajak dan free rider.

Studi tentang analisis pengenaan pajak dengan pendekatan kesetimbangan umum telah dirintis oleh Harberger (1959, 1962, 1966, 1974). Studi ini hanya memasukkan model kesetimbangan umum sederhana di mana perekonomian diasumsikan mempunyai dua sektor dan dua faktor. Model ini sulit diterapkan pada lebih dari dua faktor

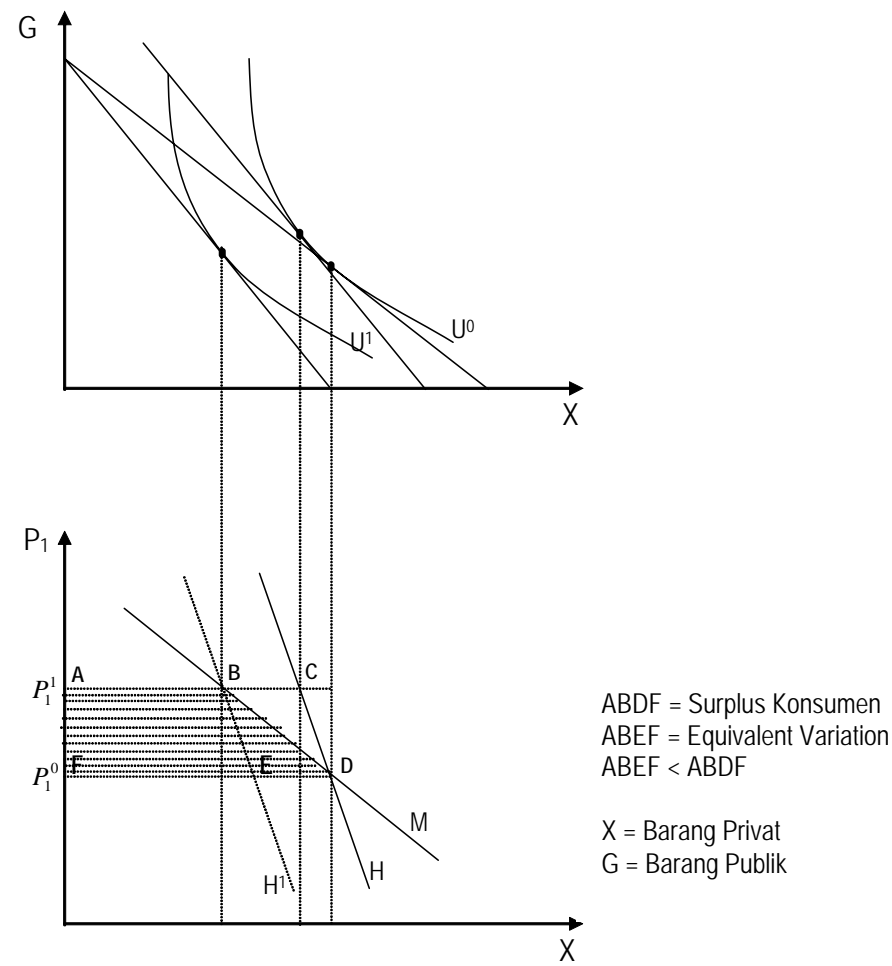

Gambar 2. Dampak Kenaikan Pajak Penghasilan terhadap Kesejahteraan 
dan dua sektor. Dengan menggunakan estimasi dari elastisitas substitusi pada produksi dan konsumsi berdasarkan literatur ekonometri, Harberger melakukan estimasi pengenaan beban pajak. Penemuan yang paling dikenal dari model ini adalah, bahwa pajak perusahaan dibebankan pada semua pemilik modal, tanpa memperhatikan apakah modal mereka digunakan pada perusahaan yang sama.

Studi tentang pengenaan pajak bukanlah hal baru di Indonesia. Isu ini menjadi populer setelah penurunan harga minyak secara tajam pada tahun 1981. Pemerintah Indonesia memutuskan untuk mengurangi ketergantungan terhadap pendapatan dari migas dengan melakukan reformasi pajak pada tahun 1984. Usaha ini didukung oleh pendapatan dari pajak non migas, terutama dari pajak penghasilan dan pajak pertambahan nilai. Sebelum reformasi pajak, kontribusi dari pajak non minyak hanya 34 persen dari total pendapatan dalam negeri, tetapi meningkat secara pasti menjadi 68 persen pada tahun 2001.

Melihat pentingnya kenaikan pajak penghasilan dan pajak pertambahan nilai, para ekonom melakukan beberapa studi untuk mengevaluasi implikasi dari jenis pajak ini di Indonesia. Pajak pertambahan nilai pertama kali dianalisis oleh Kusmanto (1989) dengan menggunakan model CGE. Sedangkan studi tentang pajak penghasilan dilakukan oleh Rochyadi-Leuthold (1994) dan Indrawati (1992). Tujuan dari studi mereka adalah mengestimasi beban pajak di Indonesia dengan menggunakan model ekonometri. Studi tersebut menunjukkan pertama, bahwa kenaikkan pajak akan meningkatkan dead weight loss yang berarti pula menurunnya tingkat kesejahteraan. Kedua, kenaikan pajak berhubungan positif dengan elastisitas penawaran tenaga kerja. Artinya semakin tinggi kenaikan pajak (upah turun) maka penawaran tenaga kerja akan turun. Fenomena ini tidak jauh berbeda dengan studi yang dilakukan di negara berkembang lainnya.

\section{PEMBAHASAN}

\section{Reformasi Pajak Penghasilan di Indonesia}

Pajak penghasilan merupakan pajak yang dikenakan kepada semua orang secara pribadi (person) dan perusahaan (sebagai subyek pajak) atas semua pendapatan atau tambahan kemampuan ekonomi yang diperolehnya dari kegiatan-kegiatan yang dilakukannya. Kegiatan tersebut meliputi bekerja, berproduksi, berinvestasi dan kegiatan-kegiatan lain yang menghasilkan pendapatan atau menambah kemampuan ekonomi.

Namun demikian, tidak semua subyek pajak harus membayar pajak atas pendapatan yang diterimanya. Hanya subyek pajak yang memenuhi kriteria tertentu, sesuai dengan peraturan yang berlaku, yang diwajibkan membayar pajak. Subyek pajak yang demikian disebut dengan wajib pajak. Jadi disini jelas bahwa untuk pajak penghasilan, subyek pajaknya adalah orang dan rumah tangga sedangkan obyek pajaknya adalah pendapatan.

Bagi orang yang tergabung dalam rumah tangga-rumah tangga, obyek pajak penghasilan adalah pendapatan yang diterima dari upah dan gaji, pendapatan atas modal (capital gain dan deviden atas saham yang dimilikinya) dan pendapatan dari bunga. Sedangkan bagi perusahaan, obyek pajak penghasilan adalah penghasilan perusahaan, penghasil- 
an neto perusahaan, keuntungan dan laba yang ditahan.

Di Indonesia perhatian terhadap pajak penghasilan baru disadari setelah terjadinya penurunan harga minyak yang tidak diperkirakan pada tahun 1981. Sejak saat itu dasar-dasar reformasi perpajakan mulai dilakukan. Reformasi pajak tersebut menitik beratkan terutama pada perluasan basis pajak dan penyederhanaan prosedur pembayaran pajak. Tujuan utama dari reformasi perpajakan diatas adalah untuk memenuhi tuntutan terhadap administrasi dan fasilitas perpajakan bagi pembayar pajak, dan dalam menekan biaya pengumpulan pajak serta mengurangi ruang untuk korupsi.
Distribusi pendapatan memainkan peranan penting dalam menggambarkan banyak keputusan final tentang reformasi perpajakan. Didasarkan pada reformasi perpajakan, tujuan dari distribusi pendapatan di Indonesia tidak dapat diatasi oleh tingginya sistem pajak yang progresif pada awal 1984. Perluasan basis pajak dari reformasi pajak, mungkin alat yang lebih efektif untuk mempertemukan tujuan dari distribusi pendapatan. Perluasan basis pajak secara jelas memberikan kontribusi pada redistribusi karena tanpa memperhatikan besarnya pendapatan yang diterima keluarga kaya (Gillis, 1985). Tabel di bawah ini menunjukkan besarnya tarif pajak penghasilan individu tahun 2000:

Tabel 1. UU RI Nomor 17 Tahun 2000 Tentang Perubahan Ketiga atas UU Nomor 7 Tahun 1983 tentang Pajak Penghasilan

\begin{tabular}{|c|c|c|c|}
\hline \multirow[t]{2}{*}{$\begin{array}{l}\text { Kelompok Harta } \\
\text { Berwujud }\end{array}$} & \multirow[t]{2}{*}{ Masa } & \multicolumn{2}{|c|}{ Tarif penyusutan sebagaimana dimaksud dalam } \\
\hline & & Ayat (1) & Ayat2) \\
\hline \multicolumn{4}{|l|}{ I. Bukan bangunan } \\
\hline Kelompok 1 & 4 tahun & $25 \%$ & $50 \%$ \\
\hline Kelompok 2 & 8 tahun & $12,5 \%$ & $25 \%$ \\
\hline Kelompok 3 & 16 tahun & $6,25 \%$ & $12,5 \%$ \\
\hline Kelompok 4 & 20 tahun & $5 \%$ & $10 \%$ \\
\hline \multicolumn{4}{|l|}{ II. Bangunan } \\
\hline Permanen & 20 tahun & $5 \%$ & \\
\hline Tidak Permanen & 10 tahun & $10 \%$ & \\
\hline \multicolumn{3}{|c|}{ Lapisan Penghasilan Kena Pajak } & Tarif Pajak \\
\hline \multicolumn{3}{|c|}{ sampai dengan $\mathrm{Rp} 25.000 .000,00$ (dua puluh lima juta rupiah) } & $5 \%$ \\
\hline \multicolumn{3}{|c|}{$\begin{array}{l}\text { di atas Rp } 25.000 .000,00 \text { (dua puluh lima juta rupiah) } \\
\text { s.d. Rp50.000.000,00(lima puluh juta rupiah) }\end{array}$} & $10 \%$ \\
\hline \multicolumn{3}{|c|}{$\begin{array}{l}\text { di atas Rp } 50.000 .000,00 \text { (lima puluh juta rupiah) } \\
\text { s.d. Rp } 100.000 .000,00 \text { (seratus juta rupiah) }\end{array}$} & $15 \%$ \\
\hline \multicolumn{2}{|c|}{ di atas Rp 100.000.000,00(seratus juta rupiah) } & $\begin{array}{l}\text { dı atas Rp 100.000.000,00(seratus juta rupiah) } \\
\text { s.d. Rp 200.000.000,00(dua ratus juta rupiah) }\end{array}$ & $25 \%$ \\
\hline \multicolumn{3}{|c|}{ di atas $\mathrm{Rp} 200.000 .000,00$ (dua ratus juta rupiah) } & $35 \%$ \\
\hline
\end{tabular}




\section{Definisi Pendapatan Rumah Tangga}

Dalam model ini, definisi dari pendapatan rumah tangga yang siap dibelanjakan, tidak hanya memasukkan pendapatan dari bekerja dan kapital tetapi juga nilai dari leisure. Besar kecilnya leisure dianggap tergantung kepada tinggi rendahnya pajak penghasilan. Dengan demikian pendapatan yang siap dibelanjakan tersebut dapat ditulis mengikuti:

$$
Y^{E}=K w\left(1-t^{h}\right)+\operatorname{Pr}\left(1-t^{h}\right)+e^{h}
$$

dimana $\mathrm{K}$ adalah total labor endowment, w adalah tingkat upah, $\mathrm{P}$ adalah property income, $\mathrm{r}$ adalah tingkat bunga, $\mathrm{t}$ adalah tingkat pajak penghasilan dan e adalah penghasilan tidak kena pajak.

Jika $K=H+L$, maka persamaan 1 dapat ditulis sebagai berikut.

$$
Y^{E}=w H+w\left(1-t^{h}\right) L+r P-T^{h}
$$

dimana $\mathrm{H}$ adalah labor supply, $\mathrm{L}$ adalah leisure time dan $\mathrm{T}$ adalah total pajak penghasilan yang dibayar oleh rumah tangga. Pajak penghasilan yang dibayar oleh setiap rumah tangga didasarkan pada labor dan property income. Setiap rumah tangga juga memiliki penghasilan yang tidak punya pajak, $\mathrm{e}^{\mathrm{h}}$. Yang dalam tulisan ini tidak diperhatikan. Pajak yang dikumpulkan dari setiap rumah tangga menjadi:

$T^{h}=t^{h}(w H+r P)-e^{h}$ atau jika e sama dengan nol, maka:

$T^{h}=t^{h}(w H+r P)$

\section{Penawaran Tenaga Kerja}

Seperti model yang digunakan oleh Ballard (1985), dalam tulisan ini pengambilan keputusan oleh rumah tangga dibedakan menjadi tiga tahap. Pertama, setelah memperhatikan besarnya pajak penghasilan, rumah tangga akan menentukan besarnya alokasi waktu untuk bekerja dan leisure. Keputusan tentang jumlah jam kerja tersebut akan menentukan besarnya pendapatan. Dengan demikian pendapatan ini sudah memperhitungkan besarnya pajak penghasilan. Inilah jumlah pendapatan yang siap dibelanjakan untuk konsumsi barang privat dan barang publik.

Jadi pada tahap pertama ini rumah tangga akan menentukan pilihan antara besarnya jumlah pendapatan (Y) dengan leisure (L). Fungsi utilitas rumah tangga tersebut adalah:

$U=f(Y, L)$

Tunduk pada kendala:

$\mathrm{Y}=\mathrm{wH}+\mathrm{P}-\mathrm{T}$

Proses optimasi terhadap persamaan (4) dan (5) akan menghasilkan fungsi penawaran tenaga kerja dan permintaan terhadap leisure. Harga dari leisure besarnya akan sama dengan tingkat upah setelah dikurangi pajak. Harga dari leisure tersebut mengukur besarnya pendapatan yang hilang dari setiap rumah tangga. Setelah pajak, upah tenaga kerja dan harga dari leisure besarnya akan sama dengan $\mathrm{w}(1-\mathrm{t})$.

\section{Tabungan Rumah Tangga}

Kedua, setiap rumah tangga menentukan jumlah uang yang digunakan untuk tabungan 
dan konsumsi. Masing masing rumah tangga memperoleh utilitas dari konsumsi sekarang dan masa depan. Dengan menggunakan fungsi Cobb-Douglass maka:

$$
U=C_{p}^{\alpha} \cdot C_{f}^{1-\alpha}
$$

dimana $\mathrm{C}_{\mathrm{p}}$ dan $\mathrm{C}_{\mathrm{f}}$ adalah konsumsi sekarang dan masa depan. Kendala anggaran adalah:

$$
Y_{p}^{E}+\frac{Y_{f}^{E}}{1+r^{d}}=P^{p} C_{p}+\frac{P^{F} C_{f}}{1+r^{d}}
$$

dimana $r^{d}$ tingkat bunga(discount rate). Dengan menyelesaikan turunan pertama sama dengan nol, kita memperoleh persamaan konsumsi sekarang sebagai berikut:

$$
P^{p} C_{p}=\alpha\left[Y_{p}^{E}+\frac{Y_{f}^{E}}{1+r^{d}}\right]
$$

Dengan demikian tabungan rumah tangga (S) adalah sama dengan perbedaan antara income dengan konsumsi sekarang.

$$
\mathrm{S}=\mathrm{Y}^{\mathrm{E}}-P^{p} C_{p}
$$

\section{Permintaan Komoditi}

Akhirnya pada tahap ketiga, masing masing rumah tangga mengalokasikan uangnya untuk membayar sejumlah komoditi baik berupa barang privat maupun barang publik. Dengan demikian utilitas dari individu sekarang adalah fungsi dari barang privat dan barang publik. Asumsikan fungsi utilitas mepunyai bentuk sebagai berikut:
$U=U(X, G)$

dimana $X$ adalah vector dari barang privat $\left(\mathrm{x}_{1}, \ldots \ldots, \mathrm{x}_{\mathrm{i}} \ldots \ldots \ldots, \mathrm{X}_{\mathrm{n}}\right)$ dan $G$ adalah kuantitas barang publik yang dikonsumsi dan dianggap tetap pada individu tersebut.

Proses optimasi terhadap persamaan (10) akan tunduk pada kendala:

$$
\sum_{i} p_{i} x_{i}=Y^{d}
$$

dimana $\mathrm{Y}^{\mathrm{d}}$ adalah pendapatan yang siap dibelanjakan (sudah memperhitungkan pajak penghasilan) setelah dikurangi tabungan. Dengan demikian fungsi permintaan adalah:

$$
X=X_{i}\left(P, Y^{d}, G\right)
$$

Secara umum barang publik merupakan fungsi dari permintaan barang privat. Berdasarkan dualisme fungsi utilitas maka masalah maksimisasi dapat dinyatakan sebagai berikut:

Minimalkan pengeluaran $\left(\sum_{i} p_{i} x_{i}\right)$ tunduk pada kendala utilitas yang didefinisikan pada persamaan (10) pada utilitas tertentu, $\bar{U}$. Proses ini akan memberikan fungsi pengeluaran:

$E(P, G, \bar{U})=Y^{d}$

Fungsi pengeluaran mempunyai sejumlah property untuk diaplikasikan dalam analisis kesejahteraan. Pertama, turunan dari fungsi pengeluaran terhadap harga akan memberikan fungsi permintaan Hicksian untuk barang tersebut yaitu: 
$\overline{x_{i}}=\frac{\partial E}{\partial P_{i}}=E_{p i}(P, G, \bar{U})$

Compensating variation dan equivalent variation yang mengukur besarnya perubahan kesejahteraan sebagai akibat perubahan harga pasar, akan lebih mudah dipahami dengan persamaan (13). Secara umum persamaan (12) apabila diturunkan terhadap G akan memberikan besarnya marginal willingness to pay setiap individu untuk membayar suatu barang publik. Bila $\bar{w}$ adalah marginal willingness to pay untuk barang publik maka;

$$
\bar{w}=-\frac{\partial E}{\partial G}=-E_{g i}(P, G, \bar{U})
$$

\section{Model Teoritis}

\section{Fungsi Utilitas}

Model dalam studi ini mengasumsikan bahwa:

a. Fungsi utilitas berbentuk CES (Tohamy and Mixon, 2004: 251)

b. Kepuasan individu ditentukan bukan saja oleh barang privat dan barang publik, tetapi juga ditentukan oleh leisure.

c. Kenaikan pajak penghasilan akan meningkatkan leisure.

d. Bahwa individu hanya bisa membelanjakan income setelah pajak untuk membeli sejumlah barang privat dan barang publik dalam memaksimumkan utilitasnya

e. Individu harus mengeluarkan sejumlah uang untuk mengkonsumsi barang publik.
Dalam menentukan keputusan jumlah leisure dan jam kerja, individu dibatasi oleh jumlah time endowment dan pendapatan, yang merupakan penjumlahan dari pendapatan karena bekerja dan tidak bekerja (property income).

Untuk setiap individu fungsi utilitas diasumsikan berbentuk CES, yaitu:

$U=\left(a Y^{b}+L^{-b}\right)^{-1 / b}$

dimana a dan b adalah parameter dari fungsi utilitas, $\mathrm{Y}$ adalah income dan $\mathrm{L}$ adalah leisure. Elastistas subsitusi antara pendapatan dan leisure, adalah s. Dimana $s=1 /(1+b)$, saat $\mathrm{s}$ positif maka $\mathrm{b}>-1$. Utilitas dimaksimalkan dengan kendala income dan waktu. Kendala income nya adalah:

$Y=w H+P-T$,

dimana w adalah tingkat upah perjam kerja, $\mathrm{H}$ adalah jumlah jam kerja, $\mathrm{P}$ adalah property income dan $\mathrm{T}$ adalah pajak penghasilan. Di sini diasumsikan bahwa pajak penghasilan dapat didekati dengan persamaan:

$T=t(w H+P)$,

dimana t, adalah tingkat pajak penghasilan individu. Dengan menggunakan persamaan (17), persamaan (16) dapat ditulis:

$Y=W H+I$,

dimana $W=w(1-t)$ dan I = P (1-t) yaitu upah dan property income setelah pajak. Kendala waktu adalah 
$k=H+L$,

dimana $\mathrm{k}$ adalah time endowment.

Proses optimasi terhadap persamaan (15) akan memberikan hasil yaitu:

$\ln (L / Y)=-s \ln a-s \ln W$

Pada saat s positif persamaan (20) menyatakan bahwa leisure income ratio mempunyai hubungan negatif dengan parameter a dan tingkat upah setelah pajak W. Dengan memecahkan persamaan (20) untuk $\mathrm{H}$ yang tidak tergantung pada $\mathrm{Y}$ dengan mensubsitusikannya pada persamaan (18) akan memberikan:

$\mathrm{H}=\frac{k-a^{-s} W^{-s} I}{1+a^{-s} W^{1-s}}$

dan, $\mathrm{L}=\mathrm{k}\left(\frac{a^{-s} W^{1-s}+a^{-s} W^{-s} I}{1+a^{-s} W^{1-s}}\right)$

Adapun prosedur untuk mendapatkan persamaan (22) adalah sebagai berikut:

Pengaruh Pajak Penghasilan pada Labor Supply dan Leisure Demand

$\operatorname{Max} X=\left(a Y^{-b}+L^{-b}\right)^{-\frac{1}{b}}$

St: $Y=W(K-L)+I$

dimana:

$\mathrm{K}=\mathrm{H}+\mathrm{L}$ $£=\left(a Y^{-b}+L^{-b}\right)^{-\frac{1}{b}}+\lambda(Y-W(K-L)-I)$

$$
\frac{\partial £}{\partial \mathrm{Y}}=-\frac{1}{\mathrm{~b}}\left(a \mathrm{Y}^{-\mathrm{b}}+\mathrm{L}^{-\mathrm{b}}\right)^{-\frac{1}{\mathrm{~b}}-1}\left(-\mathrm{baY}^{-\mathrm{b}-1}\right)+\lambda=0 \text {. }
$$

$$
\frac{\partial £}{\partial \mathrm{L}}=-\frac{1}{\mathrm{~b}}\left(a \mathrm{Y}^{-\mathrm{b}}+\mathrm{L}^{-\mathrm{b}}\right)^{-\frac{1}{\mathrm{~b}}-1}\left(-\mathrm{bL}^{-\mathrm{b}-1}\right)+\mathrm{W} \lambda=0 .
$$

Substitusi (27) dan (28), maka:

$\mathrm{aY}^{-\mathrm{b}-1}=\frac{\mathrm{L}^{-\mathrm{b}-1}}{\mathrm{~W}}$

$\left(\frac{\mathrm{L}}{\mathrm{Y}}\right)^{-(1+\mathrm{b})}=\mathrm{a} \cdot \mathrm{W}$

$\frac{\mathrm{L}}{\mathrm{Y}}=(\mathrm{a} \cdot \mathrm{W})^{-\frac{1}{1+\mathrm{b}}}$

Jika $\mathrm{s}=\frac{1}{1+\mathrm{b}}$, maka dalam bentuk log:

$\operatorname{Ln}(\mathrm{L} / \mathrm{Y})=-\mathrm{s} \operatorname{In} \mathrm{a}-\mathrm{s} \operatorname{In} \mathrm{W}$

$\frac{\mathrm{L}}{\mathrm{Y}}=(\mathrm{a} \cdot \mathrm{W})^{-s}$

dengan mensubtitusi persamaan (24) dan (25) ke persamaan (29) kita peroleh:

$\frac{\mathrm{K}-\mathrm{H}}{\mathrm{WH}+\mathrm{I}}=(\mathrm{a} \cdot \mathrm{W})^{-\mathrm{s}}$

$\mathrm{K}-\mathrm{H}=(\mathrm{a} . \mathrm{W})^{-\mathrm{s}}(\mathrm{WH}+\mathrm{I})$

$\mathrm{K}-\mathrm{H}=\mathrm{a}^{-\mathrm{s}} \mathrm{W}^{1-\mathrm{s}} \mathrm{H}+\mathrm{a}^{-\mathrm{s}} \mathrm{W}^{-\mathrm{s}} \mathrm{I}$

$\mathrm{H}\left(1+\mathrm{a}^{-\mathrm{s}} \mathrm{W}^{1-\mathrm{s}}\right)=\mathrm{K}-\mathrm{a}^{-\mathrm{s}} \mathrm{W}^{-\mathrm{s}} \mathrm{I}$

$\mathrm{H}=\frac{\mathrm{K}-\mathrm{a}^{-\mathrm{s}} \mathrm{W}^{-\mathrm{s}} \mathrm{I}}{1+\mathrm{a}^{-\mathrm{s}} \mathrm{W}^{1-\mathrm{s}}}$ 
Karena $\mathrm{K}=\mathrm{H}+\mathrm{L}$, maka

$\mathrm{K}-\mathrm{L}=\frac{\mathrm{K}-\mathrm{a}^{-\mathrm{s}} \mathrm{W}^{-\mathrm{s}} \mathrm{I}}{1+\mathrm{a}^{-\mathrm{s}} \mathrm{W}^{1-\mathrm{s}}}$, sehingga:

$\mathrm{L}=\mathrm{K}\left(\frac{\mathrm{a}^{-\mathrm{s}} \mathrm{W}^{1-\mathrm{s}}+\mathrm{a}^{-\mathrm{s}} \mathrm{W}^{-\mathrm{s}} \mathrm{I}}{1+\mathrm{a}^{-\mathrm{s}} \mathrm{W}^{1-\mathrm{s}}}\right)$

Karena $\mathrm{W}=\mathrm{w}(1-\mathrm{t})$ maka kita dapat membuktikan bahwa:

$\frac{\partial L}{\partial t}>0$, atau $\frac{\partial L}{\partial t}<0$, dan $\frac{\partial L}{\partial I}>0$,

atau $\frac{\partial L}{\partial W}<0$ artinya

dengan asumsi $\frac{\partial L}{\partial t}>0$, maka:

Jika $\quad t \uparrow \rightarrow W \downarrow \rightarrow L \uparrow$

$$
t \downarrow \rightarrow W \uparrow \rightarrow L \downarrow
$$

Jam kerja dan leisure tergantung pada time endowment, upah dan property income setelah pajak serta parameter utilitas. Sebelumnya kita tahu bahwa $W=w(1-t)$ dan $I=$ $P(1-t)$. Dengan demikian persamaan (22) dapat diturunkan terhadap $\mathrm{t}$ yang memberikan hasil:

$\frac{\partial L}{\partial t}>0$, atau $\frac{\partial L}{\partial t}<0$, yang berarti kenaikan pajak penghasilan dapat menurunkan atau meningkatkan leisure. Namun dalam tulisan ini diasumsikan bahwa kenaikan pajak penghasilan akan meningkatkan leisure. Dengan asumsi ini, income setelah pajak $\left(\mathrm{Y}_{\mathrm{t}}\right)$ menurun. Dalam tulisan ini juga diasumsikan bahwa individu hanya bisa membelanjakan income setelah pajak tersebut $\left(\mathrm{Y}_{\mathrm{t}}\right)$ untuk membeli sejumlah barang privat dan barang publik untuk memaksimumkan utilitasnya:
$Y_{t}=P_{X} X+P_{G} G$

dimana $\mathrm{P}_{\mathrm{x}}$ adalah harga barang privat dan adalah $\mathrm{P}_{\mathrm{G}}$ harga barang publik yang besarnya sama dengan nol apabila individu tersebut tidak perlu membayar dalam konsumsi barang publik. Seperti sebelumnya fungsi utilitas individu berbentuk CES yaitu:

$\mathrm{U}=\left(\alpha X^{-b}+\beta G^{-b}\right)^{-1 / b}$

Proses optimasi terhadap persamaan (34) dengan kendala persamaan (33) akan memberikan hasil sebagai berikut:

$$
X=Y_{t}^{1 / 1-b} U^{-b / 1-b} P_{X}^{-1 / 1-b} \alpha^{1 / 1-b}
$$

$G=Y_{t}^{1 / 1-b} U^{-b / 1-b} P_{G}^{-1 / 1-b} \beta^{1 / 1-b}$

Adapun prosedur perhitungan untuk mendapatkan persamaan (35) dan (36) adalah sebagai berikut:

Permintaan Barang Privat dan Barang Publik

$$
\begin{aligned}
& \operatorname{Max} \mathrm{X}=\left(\alpha \mathrm{X}^{-\mathrm{b}}+\beta \mathrm{G}^{-\mathrm{b}}\right)^{-\frac{1}{\mathrm{~b}}} \\
& \text { st : } \mathrm{Y}_{\mathrm{t}}=\mathrm{P}_{\mathrm{x}} \cdot \mathrm{X}+\mathrm{P}_{\mathrm{G}} \cdot \mathrm{G} \\
& £=\left(\alpha \mathrm{X}^{-\mathrm{b}}+\beta \mathrm{G}^{-\mathrm{b}}\right)^{-\frac{1}{\mathrm{~b}}}+ \\
& \lambda\left(\mathrm{Y}_{\mathrm{t}}-\mathrm{P}_{\mathrm{X}} \cdot \mathrm{X}-\mathrm{P}_{\mathrm{G}} \cdot \mathrm{G}\right) .
\end{aligned}
$$




$$
\begin{gathered}
\frac{\partial E}{\partial \mathrm{X}}=-\frac{1}{\mathrm{~b}}\left(\alpha \mathrm{X}^{-\mathrm{b}}+\beta \mathrm{G}^{-\mathrm{b}}\right)^{-\frac{1}{\mathrm{~b}}-1}\left(-\mathrm{b} \alpha \mathrm{X}^{-\mathrm{b}-1}\right)- \\
\lambda \mathrm{P}_{\mathrm{X}}=0 \\
\frac{\partial E}{\partial \mathrm{G}}=-\frac{1}{\mathrm{~b}}\left(\alpha \mathrm{X}^{-\mathrm{b}}+\beta \mathrm{G}^{-\mathrm{b}}\right)^{-\frac{1}{\mathrm{~b}}-1}\left(-\mathrm{b} \beta \mathrm{G}^{-\mathrm{b}-1}\right)_{-} \\
\lambda \mathrm{P}_{\mathrm{G}}=0
\end{gathered}
$$

Substitusi (40) dan (41), didapat

$$
\frac{\mathrm{P}_{\mathrm{X}} \cdot \mathrm{X}}{\mathrm{P}_{\mathrm{G}} \cdot \mathrm{G}}=\frac{\alpha \mathrm{X}^{-\mathrm{b}}}{\beta \mathrm{G}^{-\mathrm{b}}}
$$

dari persamaan (37):

$$
\begin{aligned}
& \mathrm{U}^{-\mathrm{b}}=\alpha \mathrm{X}^{-\mathrm{b}}+\beta \mathrm{G}^{-\mathrm{b}} \\
& \alpha \mathrm{X}^{-\mathrm{b}}=\mathrm{U}^{-\mathrm{b}}-\beta \mathrm{G}^{-\mathrm{b}}
\end{aligned}
$$

dari persamaan (38):

$$
\begin{aligned}
& Y t=P_{X} \cdot X+P_{G} \cdot G \\
& P_{X} \cdot X=Y t-P_{G} \cdot G
\end{aligned}
$$

Sehingga persamaan (42) dapat dirubah menjadi:

$$
\begin{aligned}
& \frac{\mathrm{Y}_{\mathrm{t}}-\mathrm{P}_{\mathrm{G}} \cdot \mathrm{G}}{\mathrm{P}_{\mathrm{G}} \cdot \mathrm{G}}=\frac{\mathrm{U}^{-\mathrm{b}}-\beta \mathrm{G}^{-\mathrm{b}}}{\beta \mathrm{G}^{-\mathrm{b}}} \\
& \frac{\mathrm{Y}_{\mathrm{t}}}{\mathrm{P}_{\mathrm{G}} \cdot \mathrm{G}}-1=\frac{\mathrm{U}^{-\mathrm{b}}}{\beta \mathrm{G}^{-\mathrm{b}}}-1 \\
& \frac{\mathrm{Y}_{\mathrm{t}}}{\mathrm{P}_{\mathrm{G}} \cdot \mathrm{G}}=\frac{\mathrm{U}^{-\mathrm{b}}}{\beta \mathrm{G}^{-\mathrm{b}}} \\
& \frac{\mathrm{P}_{\mathrm{G}} \cdot \mathrm{G}}{\beta \mathrm{G}^{-b}}=\frac{\mathrm{Y}_{\mathrm{t}}}{\mathrm{U}^{-\mathrm{b}}} \\
& \mathrm{G}^{1=\mathrm{b}}=\mathrm{Y}_{\mathrm{t}} \mathrm{U}^{\mathrm{b}} \mathrm{P}_{\mathrm{G}}^{-1} \beta \\
& \mathrm{G}=\mathrm{Y}_{\mathrm{t}}^{\frac{1}{1+\mathrm{b}}} \mathrm{U}^{\frac{\mathrm{b}}{1+\mathrm{b}}} \mathrm{P}_{\mathrm{G}}^{-\frac{1}{1+b}} \beta^{\frac{1}{1+\mathrm{b}}}
\end{aligned}
$$

$\mathrm{X}=\mathrm{Y}_{\mathrm{t}}^{\frac{1}{1+\mathrm{b}}} \mathrm{U}^{\frac{\mathrm{b}}{1+\mathrm{b}}} \mathrm{P}_{\mathrm{X}}^{-\frac{1}{1+b}} \alpha^{\frac{1}{1+\mathrm{b}}}$

dari pers (43) dan (44) kita memperoleh hasil bahwa:

$$
\begin{aligned}
& \frac{\partial \mathrm{G}}{\partial \mathrm{Y}}>0, \frac{\partial \mathrm{G}}{\partial \mathrm{U}}>0, \frac{\partial \mathrm{G}}{\partial \mathrm{P}_{\mathrm{X}}}<0 \\
& \frac{\partial \mathrm{X}}{\partial \mathrm{Y}}>0, \frac{\partial \mathrm{X}}{\partial \mathrm{U}}>0, \frac{\partial \mathrm{X}}{\partial \mathrm{P}_{\mathrm{X}}}<0
\end{aligned}
$$

Jadi, jika

$$
\begin{aligned}
& \mathrm{t} \uparrow \rightarrow \mathrm{Y} \downarrow \rightarrow \mathrm{X} \downarrow \\
& \mathrm{t} \uparrow \rightarrow \mathrm{X} \downarrow \text { dan } \mathrm{P}_{\mathrm{G}}>0 \text { maka } \mathrm{G} \downarrow
\end{aligned}
$$

Persamaan (35) dan (36) apabila diturunkan terhadap $\mathrm{Y}_{\mathrm{t}}$ akan diperoleh:

$$
\frac{\partial X}{\partial Y_{t}}>0 \text { dan } \frac{\partial G}{\partial Y_{t}}>0
$$

Hal ini berarti bahwa apabila ada kenaikan pajak penghasilan yang menyebabkan income turun maka permintaan terhadap barang privat dan barang publik sama sama mengalami penurunan. Dengan asumsi bahwa $\mathrm{P}_{\mathrm{G}}>0$ demikian sebaliknya.

\section{Analisis Kesejahteraan}

Sekarang kita akan melihat pengaruh pajak penghasilan terhadap kesejahteraan. Dalam hal ini kita menganggap bahwa kesejahteraan masyarakat adalah fungsi dari tingkat utilitas masing masing individu dalam masyarakat.

$$
\begin{aligned}
W= & W\left[U ^ { A } \left(X^{A}\left(Y^{A}\left(L^{A}, t\right), P_{x}\right),\right.\right. \\
& \left.G\left(Y^{A}\left(L^{A}, t\right), P_{G}\right)\right), U^{B}\left(X^{B}\left(Y^{B}\left(L^{B}, t\right), P_{x}\right),\right.
\end{aligned}
$$


$\left.\mathrm{G}\left(\mathrm{Y}^{\mathrm{B}}\left(\mathrm{L}^{\mathrm{B}}, \mathrm{t}\right), \mathrm{P}_{\mathrm{G}}\right)\right) \ldots \ldots .$.
$\left.\mathrm{U}^{\mathrm{N}}\left(\mathrm{X}^{\mathrm{N}}\left(\mathrm{Y}^{\mathrm{N}}\left(\mathrm{L}^{\mathrm{N}}, \mathrm{t}\right), \mathrm{P}_{\mathrm{x}}\right), \mathrm{G}\left(\mathrm{Y}^{\mathrm{N}}\left(\mathrm{L}^{\mathrm{N}}, \mathrm{t}\right), \mathrm{P}_{\mathrm{G}}\right)\right)\right]$

Dari persamaan (45) tersebut kita dapat melakukan statistika komparatif untuk melihat bagaimana pengaruh dari perubahan pajak penghasilan terhadap kesejahteraan dari setiap individu. Misalkan kita ingin melihat pengaruh dari kenaikan pajak penghasilan terhadap individu A maka akan diperoleh:

$$
\begin{aligned}
& \frac{\partial \mathrm{W}}{\partial \mathrm{U}^{\mathrm{A}}}=\frac{\partial \mathrm{W}}{\partial \mathrm{U}^{\mathrm{A}}} \frac{\partial \mathrm{U}^{\mathrm{A}}}{\partial \mathrm{X}^{\mathrm{A}}} \frac{\partial \mathrm{X}^{\mathrm{A}}}{\partial \mathrm{Y}^{\mathrm{A}}} \frac{\partial \mathrm{Y}^{\mathrm{A}}}{\partial \mathrm{L}^{\mathrm{A}}} \frac{\partial \mathrm{L}^{\mathrm{A}}}{\partial \mathrm{t}}+ \\
& \frac{\partial \mathrm{W}}{\partial \mathrm{U}^{\mathrm{A}}} \frac{\partial \mathrm{U}^{\mathrm{A}}}{\partial \mathrm{G}} \frac{\partial \mathrm{G}}{\partial \mathrm{Y}^{\mathrm{A}}} \frac{\partial \mathrm{Y}^{\mathrm{A}}}{\partial \mathrm{L}^{\mathrm{A}}} \frac{\partial \mathrm{L}^{\mathrm{A}}}{\partial \mathrm{t}}+ \\
& \frac{\partial \mathrm{W}}{\partial \mathrm{U}^{\mathrm{A}}} \frac{\partial \mathrm{U}^{\mathrm{A}}}{\partial \mathrm{G}} \frac{\partial \mathrm{G}}{\partial \mathrm{t}}+\frac{\partial \mathrm{W}}{\partial \mathrm{U}^{\mathrm{A}}} \frac{\partial \mathrm{U}^{\mathrm{A}}}{\partial \mathrm{L}^{\mathrm{A}}} \frac{\partial \mathrm{L}^{\mathrm{A}}}{\partial \mathrm{t}}>\text { atau }<0
\end{aligned}
$$

jika, $\frac{\partial W}{\partial U^{A}} \frac{\partial U^{A}}{\partial X^{A}} \frac{\partial X^{A}}{\partial Y^{A}} \frac{\partial Y^{A}}{\partial L^{A}} \frac{\partial L^{A}}{\partial t}=\mathrm{A}$

$$
\begin{aligned}
& \frac{\partial W}{\partial U^{A}} \frac{\partial U^{A}}{\partial G} \frac{\partial G}{\partial Y^{A}} \frac{\partial Y^{A}}{\partial L^{A}} \frac{\partial L^{A}}{\partial t}=\mathrm{B} \\
& \frac{\partial W}{\partial U^{A}} \frac{\partial U^{A}}{\partial G} \frac{\partial G}{\partial t}=\mathrm{C} \\
& \frac{\partial W}{\partial U^{A}} \frac{\partial U^{A}}{\partial L^{A}} \frac{\partial L^{A}}{\partial t}=\mathrm{D},
\end{aligned}
$$

dimana $\mathrm{A}<0$, $\mathrm{B}<0$ jika $\mathrm{P}_{\mathrm{G}}>0$ dan $\mathrm{B}=0$ jika $\mathrm{P}_{\mathrm{G}}=0, \mathrm{C}>0, \mathrm{D}>0$.

Dengan demikian berarti bagi individu yang membayar pajak penghasilan pengaruh dari perubahan pajak penghasilan tersebut bisa positif atau negatif. Dapat positif, apa- bila kenaikan pajak penghasilan tersebut digunakan oleh pemerintah untuk memproduksi barang publik yang lebih baik. Selain itu kenaikan tersebut akan meningkatkan leisure. Kedua hal itu menyebabkan naiknya tingkat utilitas konsumen. Jika kenaikan utilitas tersebut lebih tinggi dibandingkan penurunan utilitas akibat berkurangnya pendapatan karena pajak, maka kesejahteraan akan meningkat, demikian pula sebaliknya.

Bagi seorang free rider (individu yang tidak membayar pajak) maka:

$$
\mathrm{A} \geq 0, \mathrm{~B} \geq 0, \mathrm{C} \geq 0 \text {, dan } \mathrm{D} \geq 0 \text { sehingga }
$$
$\frac{\partial W}{\partial U^{A}} \geq 0$. Yang berarti bahwa kenaikan pajak penghasilan tersebut justru akan meningkatkan kesejahteraan mereka karena mereka tidak ikut menanggung beban pajak, sementara di sisi lain mereka ikut menikmati barang publik yang diproduksi oleh pemerintah dari hasil penerimaan pajak.

\section{KESIMPULAN}

Model teoritis dalam tulisan ini menemukan beberapa poin penting antara lain :

1. Jam kerja dan leisure tergantung pada time endowment, upah dan property income setelah pajak serta parameter utilitas.

2. Kenaikan pajak penghasilan dapat menurunkan atau meningkatkan leisure. Namun dalam tulisan ini diasumsikan bahwa kenaikan pajak penghasilan akan meningkatkan leisure. Dengan asumsi ini, income setelah pajak $\left(\mathrm{Y}_{\mathrm{t}}\right)$ menurun .

3. Dengan demikian berarti bagi individu yang membayar pajak penghasilan pengaruh dari perubahan pajak penghasilan tersebut bisa positif atau negatif. 
4. Bagi seorang free rider kenaikan pajak penghasilan tersebut justru akan meningkatkan kesejahteraan mereka .

\section{DAFTAR PUSTAKA}

Ballard, Charles L., 1987. Tax Policy and Consumer Foresight: A General Equilibrium Simulation Studi, Economic Inquiry 25, April, pp 267-284.

Boadway, Robin W and David E. Wildasin, 1988, Public Sector Economics, Little Brown and Company.

Gillis, Malcom, 1990. Value Added Taxation in Developing Countries, The World Bank Washington DC.

Indrawati, Sri Mulyani, 1992. Measuring the Labor Supply Effect of Income Taxation using Life Cycle Labor Supply Model: A Case of Indonesia, Unpublished Ph.D Dissertation, University of Illinois.

Jehle, A Geoffrey A. 1991. Advanced Microeconomic Theory, New Jersey: Prentice-Hall.

Layard, P.R.G and A.A. Walters, 1994, Microeconomic Theory, New York: McGraw-Hill Book Company.

Musgrave Richard A and Musgrave Peggy B., 1989, Public Finance in Theory and Practice. New York: McGraw-Hill Book Company, hal 231.

Rochjadi, Achmad and Jane H.Leuthold, 1994, The effect of Taxation on Labor Supply in Developing Country: Evidence from Cross-sectional Data, Journal of Economics Development and Cultural Change, Vol 42, January, pp.333-350.
Tohamy, Soumaya M. and Mixon, J. Wilson, Jr., 2004, Illustrating Consumer Theory with the CES Utility Function. Journal of Economic Education, Vol 35 No 3: pp251 Sum Heldref Publications

Varian. H, 1992. Microeconomic Analysis, WW Norton and Company. 